\title{
Pattern of two wheeler road traffic accidents in rural setting: a retrospective study
}

\author{
Vipin Gupta, Anil Kumar, Prashant Gupta, Somendra Pal Singh*, Shailendra Pal Singh, \\ Vikas Singh, Swadeep Srivastava, Shashank Verma, Ramit Chandra Singh, Mohan Singh
}

Department of Surgery, UP Rural Institute of Medical Sciences and Research, Saifai, Etawah, UP, India

Received: 22 March 2016

Accepted: 28 March 2016

*Correspondence:

Dr. Somendra Pal Singh,

E-mail: somendrachauhan@hotmail.com

Copyright: (c) the author(s), publisher and licensee Medip Academy. This is an open-access article distributed under the terms of the Creative Commons Attribution Non-Commercial License, which permits unrestricted non-commercial use, distribution, and reproduction in any medium, provided the original work is properly cited.

\begin{abstract}
Background: Roads and vehicles which are for making life comfortable and faster, can result in miserable life when one meet a road traffic accident. By 2020 road traffic accident is projected to become the third leading contributor to the global burden of disease in the world and $6^{\text {th }}$ place as a major cause of mortality worldwide. Motor cyclists are about 25 times more risk than passenger car occupants to die because of road traffic accidents. The objectives of the study were, to study pattern of two wheeler road traffic accidents in rural setting.

Methods: The present research is a retrospective analysis of all the two-wheeler accidents victim admitted in emergency, during the period ranging from September 2015 to February 2016.

Results: Among the total 2,544 patient of RTA admitted within the study period; 1,257 patients (i.e.49.41\%) were due to two-wheeler accidents. Next is pedestrian $(n=516,20.2 \%)$, light motor vehicle $(n=464,18.23 \%)$, and heavy motor vehicle accidents contribute $(n=307,12.06 \%)$.

Conclusions: lack of road driving sense and lack of knowledge of traffic rules. Regarding the type of vehicles involved in these accidents, the maximum number of accidents was due to two wheeler vehicles (scooter/motorcycle).
\end{abstract}

Keywords: Two wheeler RTA, Stray animals, Rural RTA

\section{INTRODUCTION}

As per World Health Organization, "accident" means an event, independent of human will, caused by an outside force acting suddenly leading to bodily or mental injury. Roads and vehicles which are for making life comfortable and faster, can result in miserable life when one meet a road traffic accident. By 2020 road traffic accident is projected to become the third leading contributor to the global burden of disease in the world and $6^{\text {th }}$ place as a major cause of mortality worldwide. Motor cyclists are about 25 times more risk than passenger car occupants to die because of road traffic accidents. About more than $25 \%$ of the global traffic accidental deaths occur in South East Asia region. ${ }^{1-3}$

Most of the people were young males who are the future of this developing world. There lost life setback heavy burden to country, society and family. These accidents are largely preventable, if paid proper attention to the causes leading to it.

Two wheeler riders are more vulnerable to sustain injuries as the external shell of the vehicle is absent to protect them as compared to light motor and heavy motor vehicles. Lost balance during two wheeler accidents further increases the risk of injury. The present study was undertaken to focus on the injury pattern among two wheeler accidents in and around Saifai (rural area in western Uttar Pradesh, India).

\section{METHODS}

The present study was carried out in the Department of Emergency, UP Rural Institute of Medical Sciences and Research. This rural tertiary health institute in Saifai, 
Etawah district of western Uttar Pradesh, India. The present research is a retrospective analysis of all the twowheeler accidents victim admitted in emergency, during the period ranging from September 2015 to February 2016.

\section{Inclusion and exclusion criteria}

All victims of two-wheeler accidents admitted. Twowheeler includes motor-cycles, mopeds, and bicycles. Two-wheeler accidents include all types of possible injuries, against all types of vehicles running on the road, collision with any object, surface or any animal or fall from vehicle.

Accidental details obtained the medico-legal records, police inquest, statements from witnesses/relatives and injury record from the examining doctor and the experts dealing with the injury. General examination findings and injuries are documented in the case sheath. Investigations include x-rays, ultrasonography of abdomen, NCCT head, CECT thorax and abdomen to rule out the injuries present in the victim.

Ethical commission permission has been taken for the study. This study has been ethically by UP Rural Institute of Medical Sciences and Research, Saifai, Etawah, UP, India.

\section{Data analysis}

Data was analyzed by SPSS 20.0.

\section{RESULTS}

Among the total 2,544 patient of RTA admitted within the study period; 1,257 patients (i.e. $49.41 \%$ ) were due to two-wheeler accidents. Next is pedestrian ( $n=516$, $20.2 \%)$, light motor vehicle $(\mathrm{n}=464,18.23 \%)$, and heavy motor vehicle accidents contribute $(n=307,12.06 \%)$ as shown in Table 1.

In 1257 two-wheeler victims admitted, 964 (76.69\%) were males and 293 (23.3\%) were females.
Table 1: Types of vehicle involved in total admitted RTA.

\begin{tabular}{|lll|}
\hline Type of vehicle & Frequency & Percentage \\
\hline Two wheeler & 1257 & $49.41 \%$ \\
\hline Light motor vehicle & 464 & $18.23 \%$ \\
\hline Heavy motor vehicle & 307 & $12.06 \%$ \\
\hline
\end{tabular}

Most of them were between the age group 20-30 years $(\mathrm{n}=458,36.43 \%)$ as shown in Table 2. Mean age 35.6 years and median age 27 years. Skilled labourers were the most victims $(n=358,28.5 \%)$ followed by students $(\mathrm{n}=155,12.3 \%)$. About 964 sufferers were male and 293 were females. Male to female ratio obtained as nearly 3:1.

Table 2: Age distribution.

\begin{tabular}{|lll|}
\hline Age group & Frequency & Percentage \\
\hline$<10$ years & 38 & $3.02 \%$ \\
\hline $10-20$ years & 163 & $12.96 \%$ \\
\hline 21-30 years & 458 & $36.43 \%$ \\
\hline 31-40 years & 251 & $19.96 \%$ \\
\hline $41-50$ years & 228 & $18.13 \%$ \\
\hline$>50$ years & 119 & $9.46 \%$ \\
\hline
\end{tabular}

Drivers were $892(70.96 \%)$ and pillion riders were 364 $(28.95 \%)$. Helmets were used by 301 victims in whom 292 were drivers and 9 pillion riders (Table 3). Only $32.7 \%$ (292 out of 892) drivers were wearing helmet while driving. None of the females were using helmet (Table 4).

Injuries present in victims were presented in table no 8 to Table 11. Majority of patient presented with head injury. Scalp laceration was commonly associated with head injury. Focal brain injury ( $84.8 \%$ cases) found to be more common than diffuse brain injury $(14.9 \%)$. Table 9 shows the findings obtained about head injury victims in twowheeler victims.

Many of them were associated with poly-trauma. Maxilla was fractured in $10.19 \%$ and mandible was fractured in $12.52 \%$. Incidence of vertebral fracture was about $9.06 \%$.

Table 3: Helmet used among driver and pillion rider admitted.

\begin{tabular}{|lllllll|}
\hline & Frequency & Percentage & Drivers & & \multicolumn{3}{c|}{ Pillion rider } \\
\cline { 5 - 8 } & & Frequency(n=892) & Percentage & $\begin{array}{l}\text { Frequency } \\
(\mathrm{n}=364)\end{array}$ & percentage \\
\hline Yes & 301 & $23.9 \%$ & 292 & $32.7 \%$ & 9 & $2.47 \%$ \\
\hline No & 892 & $70.9 \%$ & 536 & $60.09 \%$ & 356 & $97.8 \%$ \\
\hline Status unknown & 64 & $5.1 \%$ & 64 & $7.17 \%$ & 0 & 0 \\
\hline
\end{tabular}


External thoracic injuries are more common than the internal. Blunt force trauma to the chest can damage the organ without damaging the thoracic wall. Fractures of ribs were observed in 101 cases. Among internal thoracic injuries, lungs were the most commonly involved organ $(n=128,67.6 \%)$ followed by the heart $(n=7,3.7 \%)$. Mortality in thoracic injury was seen in $17.8 \%$ cases.
Motor bikes $(n=932,74.14 \%)$ accidents is more common in two-wheeler RTA (Table 5).

Among 1257 cases sign of alcohol intake was present in 231 victims, $20.8 \%$ of drivers and $7.5 \%$ of pillion riders (Table 6).

Table 4: Helmet used by males and females.

\begin{tabular}{|lllll|}
\hline \multirow{2}{*}{ Helmeted } & \multicolumn{2}{c}{ Males } & \multicolumn{2}{c|}{ Females } \\
\hline Yes & Frequency $(\mathrm{n}=964)$ & Percentage & Frequency $(\mathrm{n}=293)$ & Percentage \\
\hline No & 301 & $31.22 \%$ & 0 & 0 \\
\hline Status unknown & 603 & $62.5 \%$ & 289 & $98.63 \%$ \\
\hline
\end{tabular}

Table 5: Type of two-wheeler vehicle used by the admitted RTA victims.

\begin{tabular}{|lll|}
\hline Vehicles & Frequency $(\mathbf{n = 1 2 5 7})$ & Percentage \\
\hline Motor bikes & 932 & $74.14 \%$ \\
\hline Mopeds & 168 & $13.36 \%$ \\
\hline Bicycle & 157 & $12.49 \%$ \\
\hline
\end{tabular}

Table 6: Sign of alcohol intake.

\begin{tabular}{|lll|}
\hline & Frequency & Percentage \\
\hline Driver $(\mathrm{n}=892)$ & 186 & $20.8 \%$ \\
\hline Pillion driver $(\mathrm{n}=364)$ & 45 & $12.36 \%$ \\
\hline Total $(\mathrm{n}=1257)$ & 231 & $18.37 \%$ \\
\hline
\end{tabular}

Majority of accidents were front on collisions $(n=537$, 42.7\%) (Table 7).

Table 7: Nature of accident $(n=1257)$.

\begin{tabular}{|l|l|}
\hline Accident & Percentage \\
\hline Front on collision & $42.70 \%$ \\
\hline Rear end hit & $10.21 \%$ \\
\hline Skid and fall & $8.42 \%$ \\
\hline Hit while overtaking of another vehicle & $7.37 \%$ \\
\hline $\begin{array}{l}\text { Two wheeler overtaking another } \\
\text { vehicle }\end{array}$ & $6.96 \%$ \\
\hline Side on collision & $6.91 \%$ \\
\hline Fall from bike & $6.23 \%$ \\
\hline Attending mobile call while driving & $4.36 \%$ \\
\hline Hitting object/surface & $4.22 \%$ \\
\hline $\begin{array}{l}\text { Others- female sitting sideways, } \\
\text { stucking of pallu of saree or dupatta in } \\
\text { rear wheel, animals on road. }\end{array}$ & $2.61 \%$ \\
\hline
\end{tabular}

Blunt trauma abdomen 172 cases reported. Only 1 case of penetrating injury over abdomen seen. Liver was found to be the most common organ involved seen in $27.8 \%$ cases followed by spleen (19.2\%) and intestine (17.3\%) and kidney (13.6\%). Mortality in abdominal injury was seen in $15.7 \%$ cases.
Table 8: Injury pattern.

\begin{tabular}{|lll|}
\hline Injury & Frequency & Percentage \\
\hline Head injury & 587 & $46.69 \%$ \\
\hline Chest injury & 189 & $14.71 \%$ \\
\hline Abdomen & 173 & $13.76 \%$ \\
\hline Vertebral & 114 & $9.06 \%$ \\
\hline Pelvis & 92 & $7.3 \%$ \\
\hline $\begin{array}{l}\text { Limb (include injury to } \\
\text { muscle, tendon and bony } \\
\text { fractures) }\end{array}$ & 268 & $21.32 \%$ \\
\hline
\end{tabular}

Table 9: Head injury ( $n=587$ cases $)$.

\begin{tabular}{|ll|}
\hline Head injury & Percentage \\
\hline Scalp laceration & $77.3 \%$ \\
\hline Scalp fracture & $32.1 \%$ \\
\hline Focal brain injury & $84.8 \%$ \\
\hline Diffuse axonal injury & $14.9 \%$ \\
\hline SAH & $44.2 \%$ \\
\hline SDH & $20.7 \%$ \\
\hline EDH & $31.6 \%$ \\
\hline Intra-parenchymal bleed & $53.5 \%$ \\
\hline Intra-ventricular bleed & $17.9 \%$ \\
\hline Mortality & $24.7 \%$ \\
\hline
\end{tabular}

Table 10: Thoracic injury ( $n=189$ cases).

\begin{tabular}{|ll|}
\hline Thoracic injury & Percentage \\
\hline Rib fracture & $53.3 \%$ \\
\hline Lung injury & $67.6 \%$ \\
\hline Pleura & $18.2 \%$ \\
\hline Heart and pericardium & $3.7 \%$ \\
\hline Airway & $3.4 \%$ \\
\hline Esophagus & $0 \%$ \\
\hline Mortality & $17.8 \%$ \\
\hline
\end{tabular}


Table 11: Abdominal injury ( $\mathrm{n}=173$ cases).

\begin{tabular}{|ll|}
\hline Abdominal injury & Percentage \\
\hline Blunt trauma & $99.7 \%$ \\
\hline Penetrating injury & $0.3 \%$ \\
\hline Liver & $27.8 \%$ \\
\hline Spleen & $19.2 \%$ \\
\hline Kidney & $13.6 \%$ \\
\hline Pancreas & $1.1 \%$ \\
\hline Intestine & $17.3 \%$ \\
\hline Mortality & $15.7 \%$ \\
\hline
\end{tabular}

\section{DISCUSSION}

Since man created wheel, he is sitting wheels and doing accidents. Injuries to the victims of two wheeler accidents share a significant proportion of severe traffic accident injuries. The mortality rate in road traffic accident in India is one of the highest in the world and reported to be nearly 20 times more than that reported in developed countries. The majority of the vehicles driven by the victims were motor cycles (74.14\%). Skilled labourers were the most victims (28.5\%) followed by students $(12.3 \%)$. In African and western countries majority of the victims were students. ${ }^{4,5}$

The study observed that the age group of 21-30 years was most susceptible to trauma injuries. Male predominance has been observed. In our study, the male to female ratio was reported as 3:1. Similar finding has been reported in the studies done by Husaini et al. And Wong et al, Jha et al, And Kaul et al. ${ }^{6-9}$ Have reported a lower male-female ratio of 3:1 while a higher male-female ratio of 9:1 was reported by Singh and Dhattarwal. ${ }^{10}$ The increase in population and vehicles in general leading to increased congestion on the Indian roads can be directly related to the number of RTA. The common mode of accident involving riders was front on collision $(42.7 \%)$ followed by rare end hit $(10.21 \%)$. The commonest mode as per study by Nupur pruthi et al was skid and fall (45.5\%). ${ }^{11}$ Only (23.9\%) were wearing helmet in spite of helmet wearing being made a statutory requirement. None of the females were wearing helmet. Also results showed majority of victim suffered from head injury (46.69\%), which is obvious in the absence of helmet use.

Females sitting side ways as pillion rider increases the chances for the two-wheeler disbalance and many times resulting in accidents. As per social customs, female wearing Sarees or Dupatta in this region. Cases has been seen where the Pallu of the Saree or the end of the Dupatta get stuck into the rear wheel of the two-wheeler leading to accidents. The above as a cause has been reported in $2.61 \%$ which is quite significant. It has been observed the most of the accidents took place at night. Absence of tail lights in bicycle increase their chance of being the victims. Mainly elderly age group ride bicycle at night in this region. During daytime victims who were bicycle rider were mainly females of student section.
In modern day civilian trauma centers, thoracic injury directly accounts for $20-25 \%$ of deaths due to trauma; and thoracic injury or its complications are a contributing factor in a further $25 \%$ of trauma deaths. ${ }^{12}$ But our study showed $17.8 \%$ fatality cases associated with thoracic injury in two-wheeler accidents. Blunt force trauma to the chest can damage the organ without damaging the thoracic wall. External thoracic injuries are more common than the internal thoracic injury. ${ }^{13}$ Injury to the lungs and heart may be due to impact of these organs to the solid rib cage and the shearing forces to the hilum of the lungs and the heart by the impact of a moving or due to a direct impact of the fractured ribs to the heart and lungs. The lungs occupy most of the rib cage, and thus are probably more vulnerable to injury when compared to the heart. The findings of our study are in agreement with the earlier studies by other researchers. ${ }^{6,14}$

Our study significantly reported that blunt trauma abdomen incidence is largely seen in trauma due to twowheeler accidents. Liver was the most commonly affected organ followed by the spleen. Liver being the largest internal organ and owing to its anterior location is more often the target of blunt force trauma as reported in the earlier studies. ${ }^{6,9}$ Our study also showed similar results. This present study showed mortality is mainly associated with head injury $(24.7 \%)$ then followed by thoracic injury (17.8\%) and abdominal injury (15.7\%).

The victims when inquired many were not having driving license and also were unaware about the traffic rules. Other causes, such as driving in effect of alcohol and attending mobile call while driving result in road accidents. Incidence of trauma due to these things is rising in this area. There is no control over the animals present in this area. Road stray animals' occasional collision with two-wheeler also increases accidental incidence as compared to four wheeler in which minor or no trauma occurs to passengers. These injuries are largely preventable and hence remedies should be taken to reduce it incidence of RTA in this area.

\section{CONCLUSION}

A total of 1257 victims of two-wheeler road traffic accident in this part of world were studied. The whole data was analyzed for pattern and distribution of injuries in cases of two wheeler road accidents and cause of death. This may be due to lack of road driving sense and lack of knowledge of traffic rules. Regarding the type of vehicles involved in these accidents, the maximum number of accidents was due to two wheeler vehicles (scooter/motorcycle).

\section{Funding: No funding sources Conflict of interest: None declared \\ Ethical approval: The study was approved by the institutional ethics committee}




\section{REFERENCES}

1. Global burden of disease: 2004 update. Ganeva, World Health Organization, 2008. (http://www.who.int/healthinfo/global_burden_disea se/GBDreport_2004update_AnnexeA.pdf).

Accessed on 22 November 2010.

2. Traffic safety facts, 2009 Data. National highway traffic safety. U.S department of transportation. October 2011. Available at, http://wwwnrd.nhtsa.dot.gov/Pubs/811389.pdf. Accessed 20 December 2011.

3. Park JE, Park K. Textbook of preventive and social medicine. $18^{\text {th }}$ edition Jabalpur, India. M/S Banarsidas Bhanot; 2005:323-326.

4. Murray CJ, Lopez AD. Alternative projections of mortality and disability by cause 1990-2020: Glob Burden Dis Study. Lancet. 1997;349:1498-504.

5. Solagberu BA, Ofoegbu CKP, Nasir AA, Ogundipe OK, Adekanye AO, Abdur-Rahman LO. Motor cycle injuries in a developing country and vulnerability of riders, passengers and pedestrians. Injury prevention. 2006;12:266-8.

6. Husaini N, Chavan KD, Bangal RS, Singh B. Pattern of thoraco-abdominal injuries in rural region. Indian J Forensic Med Pathol. 2009;2:97103.

7. Wong ZH, Chong CK, Tai BC, Lau G. A review of fatal road traffic accidents in Singapore from 2000 to 2004. Ann Acad Med Singapore. 2009;38:594-6.
8. Jha N, Srinivasa DK, Roy G, Jagdish S. Epidemiological study of road traffic accident cases: a study from South India. Indian J Comm Med. 2004;24:20-4.

9. Kaul A, Sinha US, Pathak YK, Singh A, Kapoor AK, Sharma $S$ et al. Fatal road traffic accidents, study of distribution, nature and type of injury. J Indian Acad Forensic Med. 2005;27:71-6.

10. Singh H, Dhattarwal SK. Pattern and distribution of injuries in fatal road traffic accidents in Rohtak (Haryana). J Indian Acad Forensic Med. 2004;26:20-3.

11. Pruthi N, Chandramouli BA, Sampath S, Devi BI. Patterns of head injury among drivers and pillion riders of motorised two wheeler vehicles in Indian $\mathbf{J}$ f Neurotrauma. 2010;7(2):123-8.

12. American college of surgeons committee on trauma. Advanced trauma life support course. Chicago: American College of Surgeons. 1997;1:1-10.

13. Biswas G, Verma SK, Sharma JJ, Aggarwal NK. Pattern of road traffic accidents in North-East Delhi. J Forensic Med Toxicol. 2003;20:27-32.

14. Banerjee KK, Aggarwal BBL, Kohli A. Study of thoraco-abdominal injuries in fatal road traffic accidents in North East Delhi. J Forensic Med Toxicol. 1997;14:40-3.

Cite this article as: Gupta V, Kumar A, Gupta P, Singh SP, Pal Singh SP, Singh V, Srivastava S, Verma S, Singh RC, Singh M. Pattern of two wheeler road traffic accidents in rural setting: a retrospective study. Int Surg J 2016;3:521-5. 